\title{
JPCS
}

Peqguruang: Conference Series

Vol. 2 No. 2 Nov. 2020

elSSN: 2686-3472

\section{Graphical abstract \\ PERSEPSI MASYARAKAT TERHADAP INTRVENSI POLITIK PADA PEMILIHAN KEPALA DESA (PILKADES) DI DESA BELA KECAMATAN TAPALANG KABUPATEN MAMUJU}

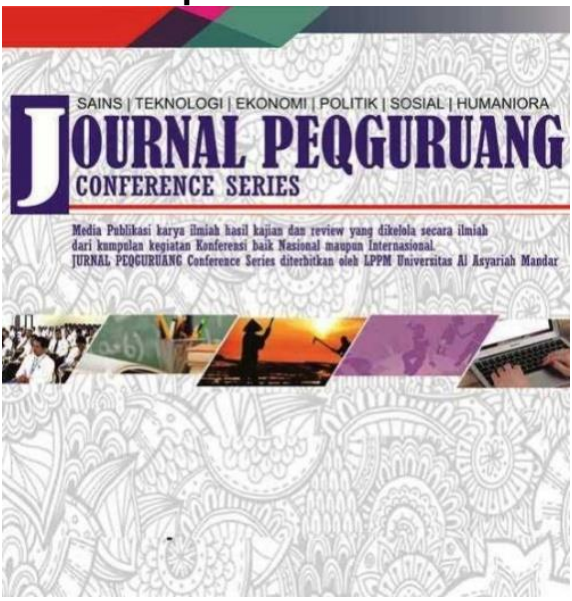

\author{
${ }^{1}$ Ahmad Al Yakin, ${ }^{1}$ Muh. Muzani Zulmaizar \\ 1*Muhammad Awawing
}

1 Universitas Al Asyariah Mandar

*awawingmuhammad@gmail.com

\begin{abstract}
This research discusses the public's perception of political intervention in the election of village heads so the main issue is the practice of political intervention in the election of village heads by political acttors. This study aims to determine understanding of the practice of political intervention and the factors that cause political intervention in the election of Village heads. As for the research method used is a qualitative type of research with descriptive patterns or depictions in analyzing public perception of the incidence of political intervention activities. And also the research techniques used are interviws and observations to collect data as well as accurate and reliable information. Based on the the research on the knwoledge and understanding of the community against the pilkades law is not minimal, but the attitudes and legal behavior in the implementation of the pilkades have not been implemented well because of the actions of political Intervention carried out by unscrupulous persons due to lack of legal awarenes.
\end{abstract}

Keywords: Perception, Political Intervention, Pilkades

\begin{abstract}
Abstrak
Penelitian ini membahas tentang persepsi masyarakat terhadap Intervensi Politik pada Pemilihan kepala Desa, maka yang menjadi pokok permasalahan adalah tentang praktek Intervensi politik pada Pilkades oleh para aktor politik. Penelitian ini bertujuan untuk mengetahui pemahaman tentang praktik intrvensi politik yang terjadi, dan faktor yang mempengaruhi terhadap Praktik Intervensi politik pada pemilihan kepala Desa. Adapun metode penelitian yang digunakan adalah pen elitian jenis kualitatif dengan pola deskriptif atau penggambaran dalam menganalisis persepsi masyarakat terhadap kejadian kegiatan Intervensi politik. Dan juga teknik penelitian yang digunakan adalah Wawancara dan juga Observasi untuk mengumpulkan Data dan juga informasi yang akurat dan terpercaya. Berdasarakan hasil penelitian penulis tentang Pengetahuan serta pemahaman masyarakat terhadap hukum Pilkades tidaklah minim akan tetapi sikap dan prilaku hukum pada penyelenggaraan Pilkades belum bisa terlaksana dengan baik karena adanya tindakan Praktik intervensi politik yang dilakukan oleh Oknum karena disebabkan kurangnya kesadaran Hukum.
\end{abstract}

Kata Kunci : Persepsi, Intervensi Politik, Pilkades

Article history

DOI: http://dx.doi.org/10.35329/jp.v2i2.976

Received : 11 Agustus 2020 | Received in revised form : 2 September 2020 | Accepted : 15 Oktober 2020 


\section{PENDAHULUAN}

Ilmu Politik mengalami perubahan yang cukup pesat dengan lahirnya berbagai penedekatan (apparoaches). Pendekatan legal (yuridis) dan instutional telah diususl dengan pendekatan Prilaku, pasca prilaku dan NeoMarxis.

Demokrasi merupakan sebuah bentuk Pmerintahan dimana semua warga negara mempunyai hak yang sama tanpa dibeda-bedakan didalam mengambil keputusan dalam yang bisa berubah kehiduan mereka. Demokrasi juga mengizinkn setiap warga Negara ikut serta baik secara langsung maupun melalui perwakian dalam perumusan, pengembangan, serta pembuatan Hukum. Demokrasi meliputi kondisi ekonomi, sosial dan budaya yang memicu adanya praktik kebebasan secara bebas dan setara. Serta demokrasi merupakan seperangkat gagasan dan Prinsip tentang kebebasaan peserta praktik dan prosedurnya. Demokrasi juga mengundang arti toleransi terhadap harkat dan martabat manusia.

Berbicara tentang kegiatan politik tentu tidak akan ada bosannya sebab politik untuk saat ini sudah merasuk dalam sendi kehdupan di kalangan masyarakat dalam kegiatan berbangsa dan bernegara, baik dalam bidan ekonomi, sosial dan budaya. Tanpa terkecuali dalam pejabat yang memag dikendalikan dan dijalankan oleh kekuasaan politik. pemegang keuasaan yang tertinggi atas tatanan pemerintahan di seluruh dunia dilakukan oleh proses politik, termasuk di NKRI, Presiden dan Wapres, kepala daerah dan wakil kepala daerah, sampai pada tingkat wilayah terkecil yakni kepala desa, kegiatan politik ini disebut dengan Pemilu. (Patria: 2015).

Pemilihan kepala desa adalah sebuah instrumen untuk membentuk pemerintahan modern dan Demokrasi, kegiatan pesta demokrasi dilaksanakan di tingkat wilayah dengan skala terkecil, ini pada kenyataannya sudah oleh Peraturan Perundangundanga Pemerintah tentang tata cara kegiatan pelaksanaan pemilihan kepala desa sehingga semua rangakaian tahapan-tahapan mulai dari pembentukan panitia pemilihan kepala desa sampai pada tahap pelantikan oleh kepala desa yang terpilih dengan harapan sesuai dengan wilayah terkecil ini pada ketentuan yang telah ditentukan. Oleh sebab itu maka proses Pilkades akan berjalan sepert yang harapkan tanpa mengganggu keutuhan masyarakat. Tentu yang menjadi harapan masyarakat dapat terpenuhi untuk terpilihnya kepala desa yang baru dan dinyatakan layak untuk menjadi pemimpin dan menjalankan sistim pemerintahannya sebagai kepala desa di desa.

Hal ini yang menjadi dambaan oleh semua kalnagan masyarakat desa demi terwujudnya keadaan yang kondusif. Namun pada kenyataannya pemilha kepala desa yang sudah diatur oleh perundangundangan pemerintah untuk saat ini sangat sulit terselenggarakan dengan berjalan lancar dan berkualitas karena adanya permanan faktor-faktor kepentingan politik tertentu. Kepentingannya yaitu karena ingin merebut kedudukan daripada apa yang sebenarnya di inginkan saat pelksanaan pemilihan kepala desa dalam pemerintahan di desa yang sah.

Kesadaran akan pentingnya kejujuran dalam pemilihan umum sering kali tidak dimiliki oleh kalanagan calon birokrasi, memperebutkan hak suara rakyat karena demi keuntungan pribadi atau pangkat dan jabatan saja tentu ini merupakan solusi yang baik lagi terpuji, Birokrasi semestinya adildan melayani masyarak dengan baik dan benar sehingga asyarakat juga merasa terpenuhi haknya dalam menerima pelayanan.

Intervnsi Politik merupakan campur tangan dari pihak lain, kegiatan ini yang kemudian sering terjadi pada saat pilkades berlangsung yang dilakukan oleh calon Kepala Desa/tim.

Pemlihan kepala desa di indonesia saat ini msih sangat memprihatinkan. Satu sisi, rakyat yang sangat bermasa bodo tidak peduli sehingga tingkat keterlibatannya dalam pemilihan kepala desa menurun. Apatisme masyarakt justru dimanfaatkan oleh kekuasaan politik. Mereka adalah elit politik yang yang dianggap melakukan tindakan Intervensi Politik.

Demikian halnya yang terjadi di kecamatan Tapalang yang terwakilkan di desa bela, saat penyelenggaraan Pemilihan Kepala desa tidak terlepas dari budaya yang dimiliki desa tersebut. Di mana masyarakat desa tersebut adalah komunitas yang homogen dikarenakan karena masyarakatnya serumpung baik dari segi agama, etnis maupun budaya. Namun demikian masih kerap kali terjadi tindakantindakan dalam pemilihan yang bertentangan dengan aturan di dalam perundang-undangan yaitu intervensi politik yang di lakukan kandidat atau tim pemenangan dipercayakan demi untuk kemenangan calon yang di unggulkan terhadap masyarakat.

\section{Pemilihan Kepala Desa (Pilkades)}

Menurut penjelasan atas Peraturan Pemerintah Republik Indonesia Nomor 72 Tahun 2005 Tentang Desa, Kepala desa dipilih langsung oleh dan dari penduduk desa warga negara RI yang telah memenuhi persyaratan. (Nugraha, 2017)

Pemilihan kepala desa diharapkan mampu dilaksanakan berdasarkan asas demokrasi. Adapun proses pemlihan kepala desa yang setidaknya perlu diketahui dimulai dari kegiatan Penjaringan dan juga penyaringan kandidat atau bakal calon kades, penetapan kandidat yang berhak ikut dipilih oleh masyarakat memilih, pendaftaran pemilih, kegiatan pelaksanaan kampanye oleh calon, pemungutan surat suara, penghtungan surat suara, penetapan calon terpilih, pengesahan, pengangkatan dan pelantikan kepala desa. (Malisa: 2013)

\section{Praktik Intervensi Politik}

Praktik ialah suatu tindakan yaang belum otomatis terwujud dalam dalam suatu tindakan (over behavior). Dalam terwujudnya sikap menjadi suatu perbedaan nyata dibutuhkan faktor pendukung atau 
suatu kondisi yang memungkinkan antara lain adalah fasilitas. Disamping fasilitas yang diperlukan juga faktor pendukung (suffort) dari pihak lain, misalnya suami dan isteri. (Notoadmojo: 2010)

Intervensi politik birokrasi merupakan suatu kegiatan yang dilakukan oleh Pejabat-pejabat Politk yang tidak sesuai dengan Birokrasi dan aturan Perundang undangan sebagai mana yang berlaku dalam Birokrasi Publik. Intervensi seperti ini sering terjadi dilakukan semata karena keuntungan Partai dan Individu Petinggi Politik tertentu. (Patria: 2015).

Politik yang sehat tentu menjadi syarat utama dalam menghasilkan masyaraat demokratis tersebut. Sebab, tanpa berjlannya politik yang sehat maka tentu masyarakat demokratis atau demokrasi itu sendiri kehilangan arahnya sehingga muncullah kebebasan yang tidak terkontrol, yang pada akhirnya mencederai demokrasi itu sendiri. ( Al Yakin, $21: 2013$ )

\section{Persepsi Masyarakat tentang Pilkades}

\section{a. Tinjauan tentang Persepsi Masyarakat}

Slameto (1995:104) mengemukakan: persepsi ialah rencana yang dimulai dari masuknya pesan atau Informasi ke dalam otak manusia. Persepsi masyarakat merupakn analisis masarakat terhadap terhadap suatu peristiwa atau obyek berupa pemahaman, penilaian dan penarikan kesimpulan terhadap suautu obyek atau peristiwa yang menjadi perhatian masyarakat tersebut, di mana obyek persepsi dalam kajian ini adalah campur tangan tokoh politik terhadap masyarakat.

\section{b. Pilkades}

Didalam mentukan kepala desa maka akan dilaksanakan pemilihan kepala desa (Pilkades) yang akan dilaksankan oleh panitia pencalonan dan Pilkades yang selanjutnya disebut dengan pantia pemilihan yang membentuk adalah Badan Perwakilan Desa beserta para jajaranya yang berperan untuk pelaksanaan kegiatan yang kaitannya dengan pelaksanaan pencalonan dan pilkades. (Akbar: 2017)

\section{METODE PENELITIAN}

\section{Jenis Penelitian}

Jenis penelitian kualitatif pola Deskriptif atau penggambaran untuk menganalisis didalam mengetahui praktek intervensi Politik, pemahaman masyarakat dan faktor yang mempengaruhi proses terjadinya Intervensi politik pada pemilihan kepala Desa.

\section{Waktu dan Tempat Penelitian}

Adapun waktu yang penelitian dilakukan mulai dari bulan september 2019 hingga bulan maret tahun 2020. Penelitian dilakukan di desa Bela Kecamatan Tapalang Kabupaten Mamuju dengan kasus Persepsi masyarakat terhadap Intervensi Politik untuk bisa mengetahui praktek yang terjadi, pemahaman Masyarakat dan juga faktor penyebab terjadinya tindakan tersebut. Salah satu alasan peneliti mengapa melakukan penelitian di Desa Bela karna peneliti sangat tertarik dengan adanya kasus tersebut. Peneliti ingin membuktikan apakah kejadian dari masalah ini benar adanya atau ini hanyalah dugaan masyarakat saja.

\section{Fokus Penelitian}

Fokus penelitian dilakukan kepada masyarakat dalam aspek pemahamann masyarakat tentang Intervensi Politik dan Faktor-faktor yang mempengaruhi terhadap tindakan Intervensi Politik pada pilkades di Desa Bela Kec. Tapalang.

\section{Subjek Penelitian}

Subjek dalam Penelitian ini berjumlah 5 orang tokoh agama, tokoh adat 4 0rang, Kepala Dusun 5 0rang, tokoh perempuan 1 0rang, Tokoh Pemuda 2 0rang, aparat desa 3 orang, penyelenggara pilkades 1 orang dan tim sukses kandindat 1 orang. Jadi jumlah totalnya 22 orang.

\begin{tabular}{|c|c|c|c|c|}
\hline \multirow[t]{2}{*}{ No } & \multirow[t]{2}{*}{ Subjek Penelitian } & \multicolumn{2}{|c|}{$\begin{array}{l}\text { Jenis } \\
\text { kelamin }\end{array}$} & \multirow[t]{2}{*}{$\underset{\mathrm{h}}{\text { Jumla }}$} \\
\hline & & $\mathrm{L}$ & $\mathrm{P}$ & \\
\hline 1. & Tokoh Agama & 5 & & 5 \\
\hline 2. & Tokoh Adat & 4 & & 4 \\
\hline 3. & Kepala Dusun & 5 & & 5 \\
\hline 4. & Tokoh perempuan & & 1 & 1 \\
\hline 5. & Tokoh Pemuda & 2 & & 2 \\
\hline 6. & Aparat Desa & 3 & & 3 \\
\hline 7. & $\begin{array}{l}\text { Tim Pemenangan } \\
\text { Kandidat }\end{array}$ & 1 & & 1 \\
\hline 8. & Penyelenggara & 1 & & 1 \\
\hline \multicolumn{4}{|c|}{ Jumlah total } & 22 \\
\hline
\end{tabular}

\section{Sumber Data}

Data primer Merupakan data yang diperoleh dari responden melalui kuesioner, kelompok fokus, sampel, panel atau juga data hasil dari data wawancara peneliti terhadap narasumber.

\section{Instrumen Penelitian}

Instrumen penelitian ialah alat yang digunakan untuk mendapatkan atau mengumpulkan data dalam rangka memecehkan masalah penelitian atau mencapai tujuan penelitian itu sendiri. (Winarno, 2013:96 ). Adapun instrumen Penelitian yang peneliti pakai yakni Observasi dan Wawancara.

\section{Teknik Pengumpulan Data}

Teknik pengumpulan data merupakan langkah peneliti mengumpulkan Data atau alat yang digunakan peneliti mengumpulkan Data serta Informasih akurat serta dan terpercaya. 
1. Wawancara

Wawancara ialah salah satu Instrumen atau alat yang dipaki dalam menggali informasi secara lisan. Ini harus dilakukan secara mendalam sehingga kita memperoleh informasi yang rill.

\section{Observasi}

Kegiatan observasi yaitu suatu kegiatan untuk mendapatkan infomasi yang dibutuhkan untuk menyajikan penggambaranyang rill pada suatu kejadian/peristiwa dalam menjawab pertanyaan pada penelitian.

\section{HASIL DAN PEMBAHASAN}

Penelitan ini dilakukan selama kurang lebih 4 bulan, dimulai bulan Januari sampai bulan Mei 2020. Penelitian ini dilakukan di Desa Bela Kec. Tapalang Kab. Mamuju.

Data yang diperoleh dalam penelitian ini adalah dan data kualitatif. Deskripsi Persepsi Masyarakat tentang Pemilihan Kepala Desa di Desa Bela.

\section{Deskripsi Pengetahuan Hukum}

Pengetahuan hukum merupakan Ilmu hukum yang tidak dapat berdiri sendiri, melainkan menbutuhkan disiplin ilmu-ilmu lain sebagai pendukung sehingga proses pelaksanaan dan penegakan hukum dapat dilakukan secara berkeadilan.

Mengenai pengetahuan hukum Peneliti melakukan wawancar bersama saudara Andi hamsis selaku tokoh pemuda.

Apakah saudara saudara tahu kalau aturan tentang Pemilihan Kepala Desa adalah aturan tertulis?

"Tahu, sebagaimana Permendagri Nomor 65 Tahun 2017 tentang Perubahan atas Permendagri NO. 112 TAHUN 2014 tentang Pilkades". (tanggal 5 April 2020, Pukul 08.30)

Apa yang Bapak ketahui tentang Pemilihan kepala Desa (Pilkades)?

"yang saya ketahui tentang Pilkades ialah pemilihan yang dilaksanakan ditingkat desa yang melibatakan calon yang dipilih dan masyarakat yang memilih untuk menentukan pemimpin di Desa di masa Mendatang".

Apakah bapak tahu atau pernah mendengar Istilah Intervensi Politik?

"yang saya tahu bahwa Intervensi Politik itu merupakan upaya yang dilakukan oleh pelaku politik untuk mempengaruhi dengan memberikan berupa tekanan pada masyarakat yang memilih untuk meminta simpati agar memberikan dukungannya".

\section{Deskripsi Pemahaman Hukum}

Hukm adlah keseluruhan peraturan yang berlakunya dapat dipaksakan oleh badan yang berwenang. Pengertian badan yang berweenang adalah badan yang kekuasaanya diakui dalam masyarakat. Pengakuan ini dapat dapat secara sosialogis, yakni berdasarkan kenyataan dari asyarakat itu seendiri, ataupun secara yuridis, yakni menurut aturan-aturan yang dibuat dalam masyarakat itu sendiri.

Demikianlah Wawancara yang dilakukan bersama bapak Suparlin selaku pelaksana Pemilihan tentang pemahaman hukum pada Pemilihan Kepala Desa dengan pertanyaan sebagai berikut.

Apakah bapak paham bahwa Pilkades itu harus Langsung, umum, bebas, jujur dan rahasia?

"Tahu, kalau pemilihan Kepala Desa langsung langsung, bebas, rahasia, jujur dan adail namun pada kenyataannya terkadang pelaksanaan Pilkades belum bisa terwujud sikap lubes tersebut karena bermainnya faktor penghambat dari berbagai banyak hal ". (Tanggal 11 Maret 2020, Pukul 8.00 )

Wawancara juga dilaukan dengan Saudara Supardi selaku tokoh Pemuda dengan pertanyaan sebagai berikut:

apa saudara paham Visi, Misi dan Program para Calon Kepala Desa?

"Paham, Karena sebelum Pemilihan Kepala Desa para calon menyamapaikannya terlebih dahulu sebelum pencoblosan dimulai”. (Tanggal 09 Maret 2020, Pukul 8.00)

Peneliti juga melakukan wawancara kepada bapak Fatta selaku kepala Dusun dengan Pertanyaan Sebagai berikut :

apa yang responden Pahami tentang Intervensi politik dalam pemilhan kepala Desa.?

"Praktik intervensi politik merupakan tindakan dalam bentuk kecurangan yang dalam pemilihan”.

\section{Deskripsi Sikap dan Perilaku Hukum}

Hukum mempunyai tujuan untuk menjaga dam memelihara ketertiban masyarakat, sekaligus memenuhi rasa keadilan manusia. Semua masyarakat tidak terkecuali harus tunduk, taat, dan bersikap positif terhadap hukum. Manfaat tunduk terhadap hukum adalah tidak terjadi sikap sewenang-wenang, adanya keseimbangan anatara hak dan kewajiban, dan terciptanya masyarakat yang aman dan tertib.

Wawancara dilakukan kepada bapak Amrillah selaku tokoh adat dengan pertanyaan sebagai berikut: 
Apakah bapak setuju bapak tidak boleh ditekan, dipaksa dan diarahkan untuk memilih orang tertentu dalam Pilkades?

"Saya sangat setuju agar supaya masyarakat memilih sesuai dengan hati nurani mereka sehingga pemilihan bisa berjalan dengan baik".

Wawancara juga dilakukan kepada bapak Asrang selaku kepala Dusun dengan Pertanyaan sebagai berikut:

Tanggapan responden menurut keikutsertaannya dalam sosialisasi pendidikan politik untuk Pilkades?

"Saya pribadi tidak pernah ikut terlibat langsung dalam kegitan seperti itu".

Wawancara juga dilakukan kepada bapak Hartono selaku tokoh agama dengan pertanyaan sebagai berikut:

Apakah bapak memilih calon kepala desa karena Kemampuan, Interitasnya dan kemampuannya?

"terkadang saya memilih calon kepala Desa karena basis kekeluargaan ditambah dengan komitmen yang disepaki bersama ketika terpilih".

\section{SIMPULAN}

Pengetahuan Hukum terhadap aturan dalam pemilihan kepala Desa, pengetahuan tentang Pilkades dan juga istilah Intervensi Politik yang dilakukan oleh oknum masyarakat. Dari komentar yang diberikan menunjukkan bahwa pengetahun masyarakat dari 3 poin diatas tidaklah minim. Pemahaman masyarakat tentang hukum seharusnya dilakukan pada kegiatan pemilihan kepala desa salah satunya bahwa pelksanaan pilkads harus Langsung, bebas, rahasia, jujur dan rahasia serta terkait sikap dan Perilaku hukum masih cenderung membawa sikap kepribadiannya didalam berpolitik tanpa harus mengedepankan prisip Umum, seperti halnya masyarakat yang memilih calon bukan melihat dari kemampuannya akan tetapi dari sistem kekeluargaan atau kerabat. Faktor tindakan intervensi karena ambisi dan kurangnya kesadaran hukum bagi pelaku intervensi dan masyarakat.

\section{DAFTAR PUSTAKA}

Al Yakin, A. (2017). Perilaku Elit Politik Ala Selebriti. Pepatudzu: Media Pendidikan dan Sosial Kemasyarakatan, 6(1), 42-53.

Akbar, Irwan. 2017,Tinjauan Yuridis Pelaksanaan Pemilihan Kepala Desa Secara Serentak Di
Kabupaten Soppeng. Prodi HukumAdsministrasi Negara Fajultas Hukum Universitas Hasanuddin Makassar, 2017

Mulisa, E., Hasyim, A., \& Nurmalisa, Y. (2013). Tinjauan Empiris Tentang Pelaksanaan Pemilihan Kepala Desa di Kecamatan Sragi Tahun 2013.

\section{Nugraha, M. A. E. (2017). PELAKSANAAN PEMILIHAN KEPALA DESA SECARA SERENTAK MENURUT UNDANG-UNDANG NOMOR 6 TAHUN 2014 TENTANG DESA (STUDI KASUS KABUPATEN SERANG).}

Patria, A. (2015). Intervensi Politik dan Netralitas Aparatur Sipil Negara dalam Pemilihan Umum Kepala Daerah Provinsi Lampung Tahun 2014 (Doctoral dissertation, Fakultas Ilmu Sosial dan Ilmu Politik).

Slameto, 1995. Belajar Dan Faktor-faktor yang Mempengaruhinya. jakarta: Rineka Cipta

Ahmad, H., Al Yakin, A., \& Sarbi, S. (2018, November). The analysis of student error in solve the problem of spherical trigonometry application. In Journal of Physics: Conference Series (Vol. 1114, No. 1, p. 012114). IOP Publishing. 